\title{
Effect of Punica and Silymarin on Hepatotoxicity Induced by Pesticides
}

\author{
Rasha Abdel-Ghany ${ }^{1}$, Shimaa Anis ${ }^{1}$, Ahmed Bihery ${ }^{2}$, Waleed Barakat ${ }^{1,3}$ \\ ${ }^{1}$ Department of Pharmacology and Toxicology, Faculty of Pharmacy, Zagazig University, Egypt \\ ${ }^{2}$ Department of Tropical Medicine, Faculty of Medicine, Zagazig University, Egypt \\ ${ }^{3}$ Department of Pharmacology and Toxicology, Faculty of Pharmacy, Tabuk University, Kingdom of \\ Saudi Arabia
}

Corresponding Author Waleed Barakat

Mobile:

002-055-2303266 /

00966544192189

\section{E mail:}

waled055@yahoo.com

Key words:

Pesticides -

hepatotoxicity - punica

- silymarin -

antioxidant - enzymes
Background and Study Aim: Human beings are exposed to pesticides through consumption of contaminated food or exposure in the occupational environment. These compounds induce hepatotoxicity through generation of reactive oxygen species. There is much evidence indicating that natural substances from medicinal plants possess powerful antioxidant activities. The aim of the present study was to investigate the potential curative effects of punica and silymarin in rats exposed to fenitrothion.

Materials and methods: Animals were randomly allocated into one of the following groups $(n=10)$ : $(C)$ control group treated with oral distilled water, $3 \mathrm{ml} / \mathrm{kg} /$ day for 42 days, (F4) oral fenitrothion, $10 \mathrm{mg} / \mathrm{kg} /$ day for 28 days, (F6) oral fenitrothion, 10 $\mathrm{mg} / \mathrm{kg} /$ day for 42 days, (Pun) fenitrothion, $10 \mathrm{mg} / \mathrm{kg} /$ day for 42 days and oral punica juice $3 \mathrm{ml} / \mathrm{kg} /$ day for 14 days starting from day 29 of fenitrorthion administration and (Sil) fenitrothion, $10 \mathrm{mg} / \mathrm{kg} / \mathrm{day}$ for 42 days and oral silymarin, $100 \mathrm{mg} / \mathrm{kg} /$ day for 14 days starting from day 29 of fenitrothion administration. Activities of hepatic enzymes including alanine aminotransferase (ALT), aspartate aminotransferase (AST), alkaline phosphatase (ALP) were evaluated. Serum albumin and total bilirubin concentrations were measured. Catalase (CAT) activity, reduced glutathione (GSH) and malondialdhyde (MDA) content in liver were determined. Total phenolic and flavonoids content were assessed in plant samples.

Results: Exposure to fenitrothion caused a significant increase in AST, ALT and ALP activities, total bilirubin concentration and a significant decrease in serum albumin. The hepatic antioxidant capacity was significantly lowered in fenitrothion- treated rats as compared to the control group $(\mathrm{p}<0.05)$. Treatment with punica or silymarin significantly ameliorated these changes.

Conclusion: This study indicated the promising therapeutic potential of punica and silymarin against hepatotoxicity induced by pesticides. These effects could be attributed to their antioxidant properties.

\section{INTRODUCTION}

In agriculture and in everyday life, to produce more and to get more profits, toxic chemicals, such as pesticides are used. But they are generating harmful consequences to animals, the environment and human health [1].

The liver plays a central role in the metabolism of substances and it can be considered as target organ of numerous chemicals used in the workplace. Many insecticides seem to be able to cause enzyme induction with the modification of hepatic metabolism of drugs and hormones, as well as significant changes in the liver. Pesticides may induce oxidative stress leading to generation of free radicals and alternated antioxidant or oxygen free radical scavenging enzyme system [2].

Minimizing oxidative stress will promote the physical condition and prevent some degenerative diseases in which free radicals are involved. There is a widespread agreement that synthetic antioxidants need to be replaced with natural antioxidants because some synthetic antioxidants have shown potential health risks. Therefore, it is 
of great importance to find new sources of safe and inexpensive antioxidants of natural origin in order to use them in modulating oxidative stress associated with chronic diseases [3].

Punica granatum (punicaceae) commonly known as pomegranate is rich in antioxidant of polyphenolic class which includes tannins, anthocynins and flavonoids. Pomegranate is the fruit of energy, vitality and medicinal value that have anthelmintic, immunostimulatory, hepatoprotective, antidiarrhoeal and anti-cancer activities [4].

Silymarin, a polyphenolic flavonoid from the milk thistle plant (Silybum marianum), inhibits lipoprotein oxidation and acts as a free-radical scavenger. Its effectiveness against multiple disorders makes it a very promising drug of natural origin. It is beneficial too, because of its wide margin of safety, easy availability and low cost. Hence, this drug may have good potential towards the treatment of many diseases, both in human beings as well as animals [5].

The present study was designed to investigate the curative effect of punica as food supplement in a model of hepatotoxicity by the organophosphorous compound; fenitrothion in rats in comparison to silymarin.

\section{MATERIALS AND METHODS}

\section{Materials:}

Fenitrothion (Sumithion $50^{\circledR,} 50 \mathrm{mg} / \mathrm{ml}$ ) was purchased from Kafr Elzayat Co. for Insecticide Ind., (Kafr Elzayat, Egypt). Fenitrothion suspension was freshly diluted in distilled water to $10 \mathrm{mg} / \mathrm{ml}$ and orally administered at a dose of $10 \mathrm{mg} / \mathrm{kg}$ [6].

Punica granatum: Ripe Punica granatum fruits, family Punicaceae were obtained from local source in Zagazig, Sharkiah, Egypt. Pomegranates were washed and manually peeled without separating the seeds. Juice was prepared using a commercial blender (Braun, ZK 200, Germany), filtered and immediately diluted with distilled water (1:3) and stored at $-20^{\circ} \mathrm{C}$ for no longer than 2 months. Aliquots were defrosted immediately and orally injected at a dose of $3 \mathrm{ml} / \mathrm{kg}$ [7].

The aqueous extract of silymarin was provided as a kind gift from MEBACO, (Arab Company for Pharmaceutical and Medicinal plants, Cairo, Egypt). Silymarin suspension was prepared by suspending $100 \mathrm{mg}$ of Silymarin extract in $1 \mathrm{ml}$ distilled water and orally injected at a dose of $100 \mathrm{mg} / \mathrm{kg}$ [8].

Voucher specimens (reference number VS020713-02-Pun and VS-020713-03-Sil) were deposited in the herbarium of the department of Pharmacology, Faculty of Pharmacy, Zagazig University, Egypt.

\section{Animals}

Male albino rats weighing $160 \pm 10 \mathrm{~g}$ were obtained from National Research Center, Cairo, Egypt and were housed in plastic cages, allowed free access to a standard diet and tap water. The rats were housed at $23 \pm 2^{\circ} \mathrm{C} 12 \mathrm{hr}$ dark/light cycle. All experimental procedures were approved by the Ethical Committee for Animal Handling at Zagazig University (ECAHZU) (NO: P7-3-2013).

Animals were randomly allocated into one of the following groups $(n=10)$ : $C$ (control group treated with oral distilled water, $3 \mathrm{ml} / \mathrm{kg} /$ day for 42 days), F4 (oral fenitrothion, $10 \mathrm{mg} / \mathrm{kg} /$ day for 28 days), F6 (oral fenitrothion, $10 \mathrm{mg} / \mathrm{kg} /$ day for 42 days), Pun (fenitrothion, $10 \mathrm{mg} / \mathrm{kg} /$ day for 42 days and oral punica juice $3 \mathrm{ml} / \mathrm{kg} /$ day for 14 days starting from day 29 of fenitrorthion administration) and Sil (fenitrothion, $10 \mathrm{mg} / \mathrm{kg} /$ day for 42 days and oral silymarin, $100 \mathrm{mg} / \mathrm{kg} /$ day for 14 days starting from day 29 of fenitrothion administration).

At the end of the experiment, after overnight fasting, blood was collected from the retroorbital plexus and centrifuged at $3500 \mathrm{rpm}$ for 15 minutes with or without heparin and serum/ plasma was collected and stored at $-20^{\circ} \mathrm{C}$. Animals were sacrificed by decapitation and liver were excised for preparation of tissue homogenates.

\section{Methods}

Total phenolic and total flavonoid contents in the plant materials were determined by colourimetric methods [9-10].

Catalase (CAT) activity, reduced glutathione (GSH) and malondialdhyde (MDA) content in liver were determined colorimetrically [11-12-13].

The following parameters were assayed in serum using kits supplied by Biodiagnostic Co (Cairo, Egypt); ALT, AST and ALP activities, total bilirubin, albumin concentrations.

\section{Statistical analysis:}

Data are expressed as means \pm SE. The statistical significance of the data was determined using one way analysis of variance (ANOVA) followed by Tukey's post hoc test using SPSS software 
package version 10 . The level of significance was taken as $\mathrm{P}<0.05$.

\section{RESULTS}

Determination of total flavonoid and total phenolic content of punica juice and silymarin extract.

The total flavonoids and total phenolics content of punica and silymarin were found to be $(228.75$ \pm 6.91 and $217.35 \pm 5.65 \mathrm{mg}$ catechin $/ 100 \mathrm{~g}$ sample) and $(37.16 \pm 0.49$ and $36.41 \pm 0.47 \mathrm{mg}$ gallic acid/ $100 \mathrm{~g}$ sample) respectively as shown in (Table 1$)$.

Determination of free radical scavenging activity of punica juice and silymarin extract.

The remaining percent of DPPH (2,2-diphenyl-1picrylhydrazyl) and $\mathrm{H}_{2} \mathrm{O}_{2}$ which is indicative of the free radical scavenging activity of punica and silymarin were found to be (12.2\% and $12.42 \%)$ and $(14.45 \%$ and 15.08$)$ respectively as shown in (Table 2).

\section{Effects on different liver functions}

Administration of fenitrothion for 28 and 42 days (F4 and F6 respectively), caused a significant increase in serum ALT, AST, ALP activities and serum total bilirubin compared with control group, while, treatment with punica or silymarin for 14 days (starting from day 29 along with fenitrothion) reversed these changes to near control values causing a significant decrease compared with F6 group (Table 3).

On the other hand, administration of fenitrothion for 28 and 42 days (F4 and F6 respectively), caused a significant decrease in albumin concentration compared with control group. Administration of punica or silymarin for 14 days (starting at day 29 days along with fenitrothion) caused a significant elevation in albumin concentration compared with F6 group (Table 3).

\section{Effect on oxidative stress biomarkers}

Administration of fenitrothion for 28 and 42 days (F4 and F6) caused a significant decrease in catalase (CAT) activity and glutathione (GSH) content in liver compared with control group. On the other hand, administration of fenitrothion for 28 and 42 days (F4 and F6) caused a significant increase in malodialdhyde (MDA) content in liver compared with control group (Table 4).

Treatment with punica or silymarin for 14 days (starting from day 29 along with fenitrothion) caused a significant increase in liver catalase activity and glutathione (GSH) content while liver malodialdhyde (MDA) content were significantly reduced (Table 4).

Table (1): Total flavonoid and phenolic content of punica juice and silymarin extract

\begin{tabular}{|l|c|c|}
\hline & $\begin{array}{c}\text { Total flavonoids (mg } \\
\text { catechin/ 100g sample) }\end{array}$ & $\begin{array}{c}\text { Total phenolics (mg gallic acid/ } \\
\text { 100g sample) }\end{array}$ \\
\hline Punica & $228.75 \pm 6.91$ & $37.16 \pm 0.49$ \\
\hline Silymarin & $217.35 \pm 5.65$ & $36.41 \pm 0.47$ \\
\hline
\end{tabular}

Table (2): Free radical scavenging activity of punica juice and silymarin extract determined by the percent remaining of DPPH and $\mathrm{H}_{2} \mathrm{O}_{2}$

\begin{tabular}{|l|c|c|}
\hline & \% remaining of $\mathbf{H}_{\mathbf{2}} \mathbf{O}_{\mathbf{2}}$ & \% remaining of DPPH \\
\hline Punica & $12.2 \%$ & $14.45 \%$ \\
\hline Silymarin & $12.42 \%$ & $15.08 \%$ \\
\hline
\end{tabular}


Table (3): Effects of fenitrothion $(10 \mathrm{mg} / \mathrm{kg})$ alone or in combination with punica $(3 \mathrm{ml} / \mathrm{kg})$ or Silymarin $(100 \mathrm{mg} / \mathrm{kg})$ on different liver functions. Data are presented as mean $\pm \mathrm{SE}$. $(\mathrm{n}=$ 10)

\begin{tabular}{|l|c|c|c|c|c|}
\hline \multicolumn{1}{|c|}{ Parameter } & Control & F4 & F6 & Pun & Sil \\
\hline Serum ALT (U/L) & $41.25 \pm 0.36$ & $54.00 \pm 0.86^{*}$ & $55.17 \pm 0.42^{* \$}$ & $45.0 \pm 0.29^{* \# \$}$ & $42.17 \pm 0.60^{\# \$}$ \\
\hline Serum AST (U/L) & $62.67 \pm 0.88$ & $146.00 \pm 4.37^{*}$ & $147.83 \pm 2.06^{* \$}$ & $114.33 \pm 0.65^{* \# \$}$ & $71.75 \pm 2.57^{\# \$}$ \\
\hline Serum ALP (U/L) & $107.59 \pm 1.61$ & $257.63 \pm 6.94^{*}$ & $236.69 \pm 6.91^{*}$ & $118.84 \pm 7.54^{\# \$}$ & $130.78 \pm 1.89^{* \# \$}$ \\
\hline $\begin{array}{l}\text { Serum total bilirubin } \\
(\mathrm{mg} / \mathrm{dl})\end{array}$ & $0.32 \pm 0.01$ & $0.89 \pm 0.01^{*}$ & $0.93 \pm 0.01^{* \$}$ & $0.59 \pm 0.02^{* \# \$}$ & $0.54 \pm 0.02^{* \# \$}$ \\
\hline $\begin{array}{l}\text { Serum albumin } \\
(\mathrm{gm} / \mathrm{dl})\end{array}$ & $4.80 \pm 0.15$ & $3.21 \pm 0.02^{*}$ & $3.28 \pm 0.04^{*}$ & $4.27 \pm 0.01^{* \# \$}$ & $4.29 \pm 0.06^{* \# \$}$ \\
\hline
\end{tabular}

Significantly different from control group

\$Significantly different from F4 group

" Significantly different from F6 group

${ }^{€}$ Significantly different from Sil group at $\mathrm{p}<0.05$ using ANOVA followed by Tukey's Post Hoc test.

Table (4): Effects of fenitrothion $(10 \mathrm{mg} / \mathrm{kg})$ alone or in combination with punica $(3 \mathrm{ml} / \mathrm{kg})$ or silymarin $(100 \mathrm{mg} / \mathrm{kg})$ on liver oxidant state catalase glutathione and malondaldahyde. Data are presented as mean \pm SE. $(n=10)$.

\begin{tabular}{|l|c|c|c|c|c|}
\hline \multicolumn{1}{|c|}{ Level } & Control & F4 & F6 & Pun & Sil \\
\hline $\begin{array}{l}\text { Catalase activity }(\mu \mathrm{mole} / \\
\text { min/mg wet tissue) }\end{array}$ & $0.60 \pm 0.01$ & $0.31 \pm 0.004^{* \#}$ & $0.25 \pm 0.002^{* \$}$ & $0.62 \pm 0.0^{* \# \$}$ & $0.61 \pm 0.01^{* \# \$}$ \\
\hline $\begin{array}{l}\text { GSH content } \\
(\mathrm{mg} / \mathrm{gm} \text { wet tissue) }\end{array}$ & $24.49 \pm 0.18$ & $15.33 \pm 0.14^{* \#}$ & $12.09 \pm 0.07^{* \$}$ & $25.26 \pm 0.21^{* \$}$ & $25.06 \pm 0.29^{* \# \$}$ \\
\hline $\begin{array}{l}\text { MDA content } \\
(\mu \mathrm{mole} / \mathrm{gm} \text { wet tissue })\end{array}$ & $56.16 \pm 1.41$ & $95.44 \pm 1.83^{* \#}$ & $95.94 \pm 3.33^{* \$}$ & $66.33 \pm 0.77^{* \# \$}$ & $64.66 \pm 1.10^{* \# \$}$ \\
\hline
\end{tabular}

Significantly different from control group,

\$Significantly different from fenitrothion 4 weeks (F4) group

\# Significantly different from fenitrothion 6 weeks (F6) group

${ }^{€}$ Significantly different from silymarin (Sil) group at $\mathrm{p}<0.05$ using ANOVA followed by LSD and Tukey' Post Hoc test.

\section{DISCUSSION}

Analysis of punica juice and silymarin extract showed the presence of flavonoids that may contribute to their antioxidant activity. These results are in accordance with previous studies showing the presence of flavonoids in punica [14] and silymarin [15].

Apart from being important dietary components, many therapeutic benefits of flavonoids are known in animal systems. Flavonoids have antioxidant, anti-proliferative, antitumor, antiinflammatory, and pro-apoptotic activities [16].

The antioxidant activity of pomegranate aril juice, attributed to a great extent to total phenols and anthocyanins content [17]. Similarly, silymarin possesses antioxidant, immunomodulatory, anticancer, antiinflammatory, antihepatoxic activities [18].

In the present study, results of DPPH and $\mathrm{H}_{2} \mathrm{O}_{2}$ reducing power indicated the high anti-oxidant activity [19] of punica juice and silymarin extract. These observations are in accordance with those reported for punica [20] and silymarin [18].

Organophosphorus pesticides are widely used in the world and causing toxic effects on nontarget organisms especially mammalian. Due to the role of liver in detoxification of environmental xenobiotics, it is at great risk of injury and induces hepatotoxicity [21].

Hepatotoxicity by pesticides may occur in many ways, such as changes in the activities of liver enzymes, serum albumin and bilirubin concentrations which account for many indices of liver function [22].

The current study has shown that fenitrothion caused a significant increase in ALT, AST and ALP activities compared with control group. Pesticides may damage liver cells and liver transaminases may be used to monitor liver damage after exposure. These results coincide 
with previous studies that showed a significant increase in liver enzymes in rats and humans exposed to organophosphorus insecticides (fenitrothion and chlorpyrifos) [23].

Furthermore, it was found that serum bile acids were the most sensitive markers for detecting liver injury, suggesting that serum bile acids could be a valuable biomarker of hepatotoxicity caused by toxics. In the present study, fenitrothion treated rats showed significant increase in the level of bilirubin which is a normal metabolic product of haemoglobin in red blood cells [24].

These results are in accordance with those obtained previously which indicated that the mechanism for pesticides hepatotoxicity is impairment of bile acid transport, causing cholestasis and subsequent hepatocellular apoptosis or necrosis [22].

The present study showed a decrease in albumin concentration following fenitrothion administration as previously stated [25]. The albumin level suppression may be due to loss of protein either by reducing in protein synthesis or increased proteolytic activity or degradation [26].

There is a considerable importance of the investigation of free radical-mediated damage to biological systems due to pesticide exposure [2728], the current study has shown that administration of fenitrothion resulted in an evident state of oxidative stress in the liver as evidenced by the decrease in catalase activity, glutathione content and increase in malodialdehyde content.

Previous studies indicate that fenitrothion intoxication can cause generation of free radicals and induce hepatic lipid peroxidation in rats [29]. Organophosphorus pesticide may induce oxidative stress which can be viewed as the disturbance in the oxidant-antioxidant balance in favor of the former [30].

Natural antioxidants from fruits and vegetables are reported to provide substantial protection that slows down the process of oxidative damage caused by reactive oxygen species (ROS) [31].

In the current study, coadministration of punica juice or silymarin extract with fenitrothion restored the altered liver functions as ALT and AST activities. These results are in accordance with those previously obtained for punica [32] and for silymarin [33]. This alleviation in ALT and AST activities may be due to stabilizing membrane integrity that prevent the leakage of intracellular enzymes [34-35].

Similarly, treatment with punica juice or silymarin extract with fenitrothion, reversed the altered ALP activity and bilirubin concentration to near normal values. These results are in accordance with those obtained previously for punica [36] and for silymarin [37].

The amelioration in ALP activity and bilirubin concentration might be attributed to the ability of polyphenols and flavonoids present in punica [32] and silymarin [33] to treat the impairment of metabolism and excretion of bilirubin.

Interestingly, administration of punica juice and silymarin extract corrected the disturbed serum albumin content. These results match those obtained previously for punica and silymarin [38]. The elevation of serum albumin might be attributed to the anabolic effect of flavonoids [39] or stimulation of RNA synthesis [40] and increased activity of mixed-function oxidation system [41].

Antioxidants play an important role in ameliorating the damaging effects of oxidative stress on cells [42]. In the current study, oral administration of punica juice or silymarin extract normalized the oxidative stress biomarkers; CAT, GSH and MDA in liver that were altered by fenitrothion. The antioxidant activity of punica and silymarin may be attributed to their content flavonoids which have been found to reduce xenobiotic-induced hepatotoxicity in animals and counteract the damaging effects of oxidative stress, cooperating with natural systems like glutathione and other endogenous protective enzymes [43].

\section{CONCLUSION}

Our findings demonstrated that punica and silymarin may be helpful in reducing the hepatotoxic adverse effects of fenitrothion by maintaining optimum cellular biochemical hemostasis.

Ethical approval: Approved.

Funding: None.

Conflict of interest: Authors declare no conflict of interest related to this article. 


\section{REFERENCES}

1- Araoud M., Neffeti F., Douki W., Hfaiedh H.B., Akrout M., Hassine M. et al. Adverse effects of pesticides on biochemical and haematological parameters in Tunisian agricultural workers. $J$ Expo Sci Environ Epidemiol 2012; 22(3), 243-247.

2- Aly N., Kawther E. G., Mahmoud F. and El-Sebae A. K. Protective effect of vitamin $\mathrm{C}$ against chlorpyrifos oxidative stress in male mice. Pesticide Biochemistry and Physiology 2010; 97(1):7-12.

3- Song F. L., Gan R. Y., Zhang Y., Xiao Q., Kuang L., Li H. B. Total phenolic contents and antioxidant capacities of selected Chinese medicinal plants. International Journal of Molecular Sciences 2010; 11(6): 2362-2372.

4- Soni H, Nayak G, Mishra K, Singhai AK, Pathak AK. Evaluation of Phyto Pharmaceutical and Antioxidant Potential of Methanolic Extract of Peel of Punica granatum. Research Journal of Pharmacy and Technology 201; 3(4): 1170-1174.

5- Govind P, Sahni YP. A review on hepatoprotective activity of silymarin. International Journal of Research in Ayurveda and Pharmacy 2011; 2(1): 75-79.

6- Korany NS, Ezzat BA. Prophylactic effect of green tea and Nigella sativa extracts against fenitrothioninduced toxicity in rat parotid gland. Arch Oral Biol 2011;56: 1339-1346.

7- Faria A, Monteiro R, Mateus N, Azevedo I, Calhau C. Effect of pomegranate (Punica granatum) juice intake on hepatic oxidative stress. Eur J Nutr 2007;46: 271-278.

8- Galal RM, Zaki HF, Seif El-Nasr MM, Agha AM. Potential protective effect of honey against paracetamol-induced hepatotoxicity. Arch Iran Med 2012;15: 674-680.

9- Spanos GA, Wrolstad RE. Influence of processing and storage on the phenolic composition of Thompson Seedless grape juice. J. Agric. Food. Chem. 1990;38:1565-1571.

10- Zhishen J, Mengcheng $\mathrm{T}$, Jianming $\mathrm{W}$. The determination of flavonoid contents in mulberry and their scavenging effects on superoxide radicals. Food Chem. 1999;64: 555-559.

11- Beutler E, Duron O, Kelly BM. Improved method for the determination of blood glutathione. $J \mathrm{Lab}$ Clin Med 1963;61: 882-888.

12- Sinha AK . Colorimetric assay of catalase. Anal Biochem 1972;47: 389-394.
13- Yoshioka T, Kawada K, Shimada T, Mori M. Lipid peroxidation in maternal and cord blood and protective mechanism against activated-oxygen toxicity in the blood. Am J Obstet Gynecol 1979; 135: 372-376.

14- Aviram M, Dornfeld L, Kaplan M, Coleman R, Gaitini D, Nitecki S et al.. Pomegranate juice flavonoids inhibit low-density lipoprotein oxidation and cardiovascular diseases: studies in atherosclerotic mice and in humans. Drugs Exp Clin Res 2002; 28: 49-62.

15- Valenzuela A, Garrido A. Biochemical bases of the pharmacological action of the flavonoid Silymarin and of its structural isomer silibinin. Biol Res 1994;27: 105-112.

16- Buer CS, Imin N, Djordjevic MA. Flavonoids: new roles for old molecules. Journal of Integrative Plant Biology 2010; 52(1): 98-111.

17- Cassano A, Conidi C, Drioli, E. Clarification and concentration of pomegranate juice (Punica granatum L.) using membrane processes. Journal of Food Engineering 2011; 107(3): 366-373.

18- Shaker E, Mahmoud H, Mnaa S. Silymarin , the antioxidant component and Silybum marianum extracts prevent liver damage. Food Chem Toxicol 2010; 48: 803-806.

19- Garcia EJ, Oldoni TL, Alencar SM, Reis A, Loguercio AD, Grande RH. Antioxidant activity by DPPH assay of potential solutions to be applied on bleached teeth. Braz Dent J 2012;23: 22-27.

20- Mensor LL, Menezes FS, Leitao GG, Reis AS, dos Santos TC, Coube CS et al.. Screening of Brazilian plant extracts for antioxidant activity by the use of DPPH free radical method. Phytother Res 2001;15: 127-130.

21- Heikal TM, El-Sherbiny Mahmoud, Hassan SA, Arafa, Azza, Ghanem, HZ. Antioxidant effect of selenium on hepatotoxicity induced by chlorpyrifos in male rats. Int J Pharm Pharm Sci 2012; 4(4): 603-609.

22- Cataudella E, Malaguarnera G, Gagliano C, Condorelli G, Antic T, Rampello L et al. Pesticides exposure and the management of acute hepatic injury. Acta Medica 2012; 28: 245.

23- Patil JA, Patil AJ, Govindwar SP. Biochemical effects of various pesticides on sprayers of grape gardens. Indian J Clin Biochem 2003;18: 16-22.

24- Oh SW, Lee ES, Kim S, Na KY, Chae DW, Chin HJ. Bilirubin attenuates the renal tubular injury by inhibition of oxidative stress and apoptosis. BMC Nephrol 2003;14, 105. 
25- Ogutcu A, Suludere Z, Kalender Y. Dichlorvosinduced hepatotoxicity in rats and the protective effects of vitamins $\mathrm{C}$ and E. Environ Toxicol Pharmacol 2008;26, 355-361.

26- Heneghan C, Alonso-Coello P, Garcia-Alamino JM, Perera R, Meats E, Glasziou P. Selfmonitoring of oral anticoagulation: a systematic review and meta-analysis. Lancet 2006;367: 404411.

27- Eskenazi B, Marks AR, Bradman A, Harley K, Barr DB, Johnson $\mathrm{C}$ et al.. Organophosphate pesticide exposure and neurodevelopment in young Mexican-American children. Environ Health Perspect 2007;115: 792-798.

28- Milatovic D, Gupta RC, Aschner M. Anticholinesterase toxicity and oxidative stress. Scientific World Journal 2006;6: 295-310.

29- Kalender S, Uzun FG, Durak D, Demir F, Kalender Y. Malathion-induced hepato-toxicity in rats: the effects of vitamins $\mathrm{C}$ and E. Food Chem Toxicol 2010;48: 633-638.

30- Kovacic P. Mechanism of organophosphates (nerve gases and pesticides) and antidotes: electron transfer and oxidative stress. Curr Med Chem 2003;10: 2705-2709.

31- Carratu B, Federici E, Gallo FR, Geraci A, Guidotti M, Multari $\mathrm{G}$ et al.. Plants and parts of plants used in food supplements: an approach to their safety assessments. Ann Ist Super Sanita 2010;46: 370388.

32- Toklu HZ, Dumlu MU, Sehirli O, Ercan F, Gedik $\mathrm{N}$, Gokmen V et al.. Pomegranate peel extract prevents liver fibrosis in biliary-obstructed rats. $J$ Pharm Pharmacol 2007;59: 1287-1295.

33- Pradeep K, Mohan CV, Gobianand K, Karthikeyan S. Silymarin modulates the oxidantantioxidant imbalance during diethyl-nitrosamine induced oxidative stress in rats. Eur J Pharmacol 2007; 560: 110-116.

34- Arun M, Asha VV. Preliminary studies on antihepatotoxic effect of Physalis peruviana Linn. (Solanaceae) against carbon tetrachloride induced acute liver injury in rats. $J$ Ethnopharmacol 2007;111: 110-114.
35- Wu SJ, Ng LT, Chen CH, Lin DL, Wang SS, Lin CC. Antihepatoma activity of Physalis angulata and $P$. peruviana extracts and their effects on apoptosis in human Hep G2 cells. Life Sci 2004;74: 2061-2073.

36- Abdel-Moneim AE, Dkhil MA, Al-Quraishy S. The redox status in rats treated with flaxseed oil and lead-induced hepatotoxicity. Biol Trace Elem Res 2010;143: 457-467.

37- Wu JW, Lin LC, Tsai TH. Drug-drug interactions of Silymarin on the perspective of pharmacokinetics. J Ethnopharmacol 2009;121: 185-193.

38- Osman M, Ahmed M, Mahfouz S, Elaby S. Biochemical studies on the hepato-protective effects of pomegranate and guava ethanol extracts. New York Sci. J. 2011;4(3):27-39.

39- El Saeed, Taha TA, Hassan ME, Amany MS. Modulatory effects of artichock leave extract on nandrolone decanoate-induced biochemical alterations in rats. Glob J Biotechnol Biochem 2012; 7: 68-78.

40- Shaker ME, Shiha GE, Ibrahim TM. Comparison of early treatment with low doses of nilotinib, imatinib and a clinically relevant dose of Silymarin in thioacetamide-induced liver fibrosis. Eur $J$ Pharmacol 2011;670: 593-600.

41- Crocenzi FA, Pellegrino JM, Sanchez Pozzi EJ, Mottino AD, Garay EA, Roma MG. Effect of Silymarin on biliary bile salt secretion in the rat. Biochem Pharmacol 2000;59: 1015-1022.

42- Youdim KA, Qaiser MZ, Begley DJ, Rice-Evans CA, Abbott NJ. Flavonoid permeability across an in situ model of the blood-brain barrier. Free Radic Biol Med 2004;36: 592-604.

43- El-Beshbishy HA, Tork OM, El-Bab MF, Autifi MA. Antioxidant and antiapoptotic effects of green tea polyphenols against azathioprine-induced liver injury in rats. Pathophysiology 2011;18: 125-135.

Peer reviewer: Tarik Zaher, Professor of Tropical Medicine and Hepatogastroenterology, Faculty of Medicine, Zagazig University, Egypt. Editor: Mohamad Emara, Assistant Professor of Tropical Medicine and Hepatogastroenterology, Faculty of Medicine, Zagazig University, Egypt 